\title{
PIJAT BAYI MEMPENGARUHI BERAT BADAN BAYI DAN POLA TIDUR BAYI USIA 2-6 BULAN
}

\author{
Sri Dinengsih ${ }^{1 *}$, Refina Eka Yustiana² \\ 1,2Universitas Nasional Jakarta \\ *Korespondensi : email dini_alba@yahoo.com/sridinengsih@civitas.unas.ac.id
}

\section{ABSTRACT BABY MASSAGE INFLUENCES A BABY'S WEIGHTAND SLEEP PATTERNS FOR 2-6 MONTHS AGE}

Background babies are very sensitive and delicate creatures, have needs that must be met, including physical, biological and emotional needs. Optimal growth and development of babies often experience disturbances or obstacles, one of which is weight gain and baby sleep patterns.

Purpose of this study was to determine the effect of baby massage on weight gain and sleep patterns for babies aged 2-6 months in BPM Bidan E Kurnia Garut Regency in 2020.

Methods is a pre-experimental design, with a pre-experimental research design with Intact-Group. Comparison. The samples of this study were 48 babies, 24 babies as the experimental group and 24 babies as the control group. Data collection used observation sheets. Data analysis used the $T$ test.

Results showed that the baby's weight in the control group was 6137.5 grams, while in the experimental group the baby's weight was 6729.2 grams. The baby's sleep pattern in the control group was 12.7 hours, while in the experimental group the sleep pattern was 14.6 hours.

Conclusion there is an effect of infant massage on weight gain and sleep patterns in infants. Suggestion:Improving health education, counseling and demonstrations about infant massage to mothers

Keywords: Massage baby, body weight, sleep patterns

\section{ABSTRAK}

Latar Belakang bayi merupakan makhluk yang sangat peka dan halus, memiliki kebutuhan yang harus dipenuhi meliputi kebutuhan fisik, biologis serta emosi. Pertumbuhan dan perkembangan bayi yang optimal sering sekali mengalami gangguan atau hambatan salah satunya adalah kenaikan berat badan dan pola tidur bayi.

Tujuan penelitian ini untuk mengetahui pengaruh pijat bayi terhadap peningkatan berat badan dan pola tidur bayi usia 2-6 bulan di BPM Bidan E Kurnia Kabupaten Garut Tahun 2020.

Metode penelitian Pre-experimental design, dengan desain penelitian pre-eksperimen dengan pretest dan post test desain. Sampel penelitian ini adalah 48 bayi, 24 bayi sebagai kelompok eksperimen dan 24 bayi sebagai kelompok kontrol. Pengumpulan data menggunakn lembar observasi.Analisis data menggunakan uji T independent.

Hasil penelitian menunjukkan bahwa berat badan bayi pada kelompok kontrol adalah 6137,5 gram, sedangkan pada kelompok eksperimen berat badan bayi adalah 6729,2 gram. pola tidur bayi pada kelompok kontrol adalah 12,7 jam, sedangkan pada kelompok eksperimen pola tidurnya adalah 14,6 jam.

Kesimpulan ada pengaruh pijat bayi terhadap peningkatan berat badan dan pola tidur pada bayi .

Saran meningkatkan pendidikan kesehatan, penyuluhan dan demonstrasi tentang pijat bayi kepada ibu

Kata Kunci : Pijat bayi, berat badan, pola tidur

\section{PENDAHULUAN}

Indonesia termasuk negara yang memiliki permasalahan penyakit akibat gizi kurang hingga sekarang. prevalensi anak yang mengalami gizi kurang menurun dari $14.43 \%$ tahun 2016 menjadi $14.00 \%$ tahun 2017 dan telah memenuhi target yang ditetapkan oleh pemerintah sesuai dengan kesepakatan sasaran pembangunan millennium
(Millennium Development Goal's) MDG's 2015 yaitu sebesar $15,50 \%$ (Riskesdas, 2018)

Diantara 33 propinsi di Indonesia 19 provinsi memiliki prevalensi gizi buruk dan kurang diatas angka prevalensi nasional yaitu berkisar antara $21,2 \%$ sampai dengan $33,1 \%$. Jawa Barat termasuk salah satu dari 19 provinsi yang memiliki prevalensi gizi buruk-kurang yaitu menempati 


\section{JKM (Jurnal Kebidanan Malahayati),Vol 7,No.2.April 2021, \\ ISSN (Print) 2476-8944 ISSN (Online) 2579-762X, Hal 332-339}

urutan ke 15, sementara itu jumlah gizi buruk di Kabupaten Garut sebanyak 3,9\% dan gizi kurang 13,8\% (Kemenkes RI, 2018).

Masalah gizi buruk memiliki dampak diantaranya adalah menghambat pertumbuhan fisik maupun mental. Masalah lainnya adalah penurunan daya tahan tubuh, sehingga dapat meningkatkan terjadinya infeksi. Kekurangan gizi akan menyebabkan hilangnya masa hidup sehat balita. Dampak jangka pendeknya adalah meningkatkan angka morbiditas dan dampak jangka panjang adalah rendahnya kualitas sumber daya manusia (SDM) mendatang yang dilihat dari kecerdasan, kreativitas, dan produktivitasnya (Kemenkes, 2014).

Berat badan merupakan hasil peningkatan atau penurunan semua jaringan pada tubuh antara lain tulang, otot, lemak, cairan tubuh. Pada saat ini berat badan dipakai sebagai indikator untuk mengetahui keadaan gizi dan tumbuh kembang anak karena berat badan sensitif terhadap perubahan walaupun sedikit. Tidur yang tidak berkualitas adalah dimana bayi mengalami gangguan tidur jika pada malam hari tidurnya kurang dari 9 jam, terbangun lebih dari 3 kali dan lama terbangunnya lebih dari 1 jam. Selama tidur bayi terlihat selalu rewel, menangis dan sulit jatuh tidur kembali. Bila hal tersebut sering terjadi pada kebiasaan tidur bayi, maka akan sangat mempengaruhi pertumbuhan anak, baik secara fisik maupun psikis ( Roesli, 2013 dalam Fauziah, 2018).

Salah satu upaya untuk meningkatkan berat badan bayi dan memperbaiki pola tidur bayi adalah dengan diberikan stimulasi atau rangsangan. Stimulasi atau rangsangan yang baik untuk anak dapat diberikan oleh orang tua untuk perkembangan potensinya secara maksimal. Faktor yang berhubungan dengan tumbuh kembang anak yaitu nutrisi yang tercukupi, lingkungan keluarga yang mendukung merupakan dasar untuk tumbuh kembang anak. Selain itu dari segi personal anak dapat diberikan stimulasi, salah satu bentuk stimulasi yang umum dilakukan orang tua untuk bayi adalah stimulasi taktil dalam bentuk pijat bayi(Adriana, 2013).

Pijat bayi sudah beberapa waktu ini digemari karena bisa membuat bayi lebih sehat dan tidak rewel. Pijat bayi juga bisa membuat otot bayi lebih kuat, imunitasnya meningkat, menaikkan berat badan bayi, mengurangi rasa sakit, dan membuat tidur bayi lebih lelap. Pijat bayi bisa merangsang otot motorik, memperbaiki kekebalannya serta menambah jumlah produksi darah putih yang membuat menjadi lebih sehat.

Pijatan pada bayi tidak hanya memberi efek rileks, tapi juga merupakan salah satu cara memberi stimulan pada seluruh perkembangan indera bayi, meningkatkan berat badan dan merangsang pertumbuhan. Terapi sentuh khususnya pijat terbukti dapat menghasilkan perubahan fisiologis yang menguntungkan, yang dapat diukur secara ilmiah. Pengukuran secara ilmiah ini dapat diukur dari kadar cortisol ludah, kadar cortisol plasma secara radio immunoassy, kadar hormon stress (catecholamine) air seni, dan pemeriksaan EEG (Electro Encephalogram/ gambaran gelombang otak (Fauziah, 2018)

Studi pendahuluan yang peneliti lakukan berdasarkan hasil wawancara yang dilakukan peneliti pada saat jadwal imunisasi kepada sepuluh ibu yang memiliki bayi mengenai pijat bayi didapatkan bahwa $90 \%$ ibu tersebut menyatakan tidak mengetahui manfaat pijat bayi dan belum pernah melakukan pijat bayi kepada anaknya. Selain itu 2 orang ibu mengatakan bahwa bayinya mengalami berat badan yang sulit naik dalam 2 bulan ini.

Tujuan dari penelitian ini yaitu untuk mengetahui pengaruh pijat bayi terhadap peningkatan berat badan dan pola tidur bayi usia 26 bulan di Praktek Mandiri Bidan Kurnia Kabupaten Garut Tahun 2020.

\section{METODE PENELITIAN}

Penelitian Ini di laksanakan di Praktek Mandiri Bidan kabupaten Garut pada bulan Jumi sampai Juli 2020 dan mengunakan metode penelitian Pretest Post test Desain Responden yang digunakan yaitu bayi usia 2-6 bulan sebanyak 24 bayi kelompok kontrol dan 24 bayi dengan kelompok eksperimen yang diambil dengan Teknik accidental sampling. Kelompok eksperimen diberikan Booklet pijat bayi yang dilengkapi dengan cara cara pijat bayi, Instrumen penelitian ini lembar ceklis berat badan pada awal dan akhir penelitian, baby oil dan video pijat bayi yang dibagikan langsung kepada orang tua dari bayi usia 2-6 bulan, dan Timbangan berat badan bayi dengan kapasitas maksimalnya $20 \mathrm{~kg}$. Pada penelitian ini bayi akan di pijat lebih kurang $2 \times 15$ menit dalam satu hari (pagi, siang/sore dan malam hari) selama 2 minggu Sebelumnya bayi ditimbang terlebih dahulu untuk mengetahui berat badan sebelum ditimbang (pretest). Penimbangan terakhir (post-test) lakukan pada hari ke-14 pada pola tidur peneliti akan mengisi lembar observasi dengan hasil ukur 2 kategori 1.nyenyak (14-16 jam dan 2. kurang nyenyak $(<14$ jam) melalui wawancara Semua subjek penelitian telah menyetujui dan menandatangani inform consent 
Data yang di catat adalah kesimpulan hasil observasi dengan mengunakan lembar observasi dan Timbangan berat badan bayi dengan kapasitas maksimalnya $20 \mathrm{~kg}$. Proses pengumpulan data dilakukan dengan berat badan bayi serta pola tidur bayi. Teknik Analisis data bivariat mengunakan uji $T$ Independentt.

Data yang di catat adalah kesimpulan hasil observasi dengan mengunakan lembar observasi dan Timbangan berat badan bayi dengan kapasitas maksimalnya $20 \mathrm{~kg}$. Proses pengumpulan data dilakukan dengan berat badan bayi serta pola tidur bayi. Teknik Analisis data bivariat mengunakan uji $T$ Independentt.

\section{HASIL DAN PEMBAHASAN Karakteristik Responden}

Tabel 1 menunjukkan bahwa jumlah responden yang berjenis kelamin laki-laki pada kelompok kontrol sebanyak 15 orang $(62,5 \%)$ dan jumlah perempuan sebanyak 9 orang $(37,5 \%)$, sedangkan pada kelompok eksperimen jumlah lakilaki sebanyak 13 orang $(54,2 \%)$ dan perempuan sebanyak 11 orang $(45,8 \%)$

Tabel 1.

Distribusi Frekuensi Karakteristik Responden Berdasarkan Jenis Kelamin

\begin{tabular}{lcc}
\hline Kelompok & $\begin{array}{c}\mathbf{F} \\
\text { (Frekuensi) }\end{array}$ & $\begin{array}{c}\% \\
\text { (Persentase) }\end{array}$ \\
\hline Kontrol & & \\
Laki-laki & 15 & 62,5 \\
Perempuan & 9 & 37,5 \\
Eksperimen & & \\
Laki-laki & 13 & 54,2 \\
Perempuan & 11 & 45,8 \\
\hline \multicolumn{1}{c}{ Total } & 24 & 100 \\
\hline
\end{tabular}

Tabel 2.

Uji Homogenitas pada Varian Test Awal (Pretest) Berat Badan dan Pola Tidur Bayi

\begin{tabular}{lcccc}
\hline \multicolumn{1}{c}{ Variabel } & Levene Statistic & df 1 & df 2 & Sig \\
\hline Berat badan & 0,873 & 1 & 46 & 0,552 \\
Pola Tidur & 0,359 & 1 & 46 & 0,355 \\
\hline
\end{tabular}

Berdasarkan Tabel 2 menunjukkan bahwa nilai signifikan yang diperoleh variabel berat badan sebesar 0,552, sedangkan pada variabel pola tidur 0,355 , kedua nilai yang diperoleh lebih besar daripada nilai a $(0,05)$, maka HO diterima. Hal ini berarti bahwa kedua data variabel pada kelompok kontrol dan eksperiment mempunyai varian yang homogen

Tabel 3.

Perbedaan berat badan bayi pada Masing- Masing Kelompok

\begin{tabular}{lcccccc}
\hline \multicolumn{1}{c}{ Kelompok } & N & Mean & Min & Mak & Sd & Se \\
\hline Kontrol & & & & & & \\
Pretest & 24 & 6137,5 & 5400 & 7600 & 615,6 & 125,7 \\
Posttest & 24 & 6129,2 & 5300 & 7500 & 604,9 & 123,5 \\
Eksperimen & & & & & & \\
Pretest & 24 & 6729,2 & 5300 & 8500 & 764,1 & 155,9 \\
Posttest & 24 & 6912,5 & 5500 & 8800 & 778,7 & 158,9 \\
\hline
\end{tabular}

Tabel 3 menunjukkan bahwa rata-rata berat badan bayi pada kelompok kontrol pretest di BPM Bidan E Kurnia Kabupaten Garut tahun 2020 sebesar 6137,5 gram dengan standar deviasi 615,5, berat badan tertinggi sebesar 7600 gram dan berat badan terendah sebesar 7500 gram, sedangkan rata-rata berat badan bayi posttest sebesar 6129,2 gram, dengan standar deviasi 604,9 , berat badan bayi tertinggi sebesar 7500 gram dan terendah 5300 gram
Rata-rata berat badan bayi pada kelompok eksperiment pretest di BPM Bidan E Kurnia Kabupaten Garut tahun 2020 sebesar 6729,2 gram dengan standar deviasi 764,1 , berat badan tertinggi sebesar 8500 gram dan berat badan terendah sebesar 5300 gram, sedangkan rata-rata berat badan bayi posttest sebesar 6912,5 gram, dengan standar deviasi 778,7 , berat badan bayi tertinggi sebesar 8800 gram dan terendah 5500 gram 
JKM (Jurnal Kebidanan Malahayati),Vol 7,No.2.April 2021,

ISSN (Print) 2476-8944 ISSN (Online) 2579-762X, Hal 332-339

Tabel 4 menunjukkan bahwa rata-rata pola tidur bayi pada kelompok kontrol pretest di BPM Bidan E Kurnia Kabupaten Garut tahun 2020 sebesar 12,3 jam dengan standar deviasi 1,49, pola tidur tertinggi sebesar 15 jam dan pola tidur terendah sebesar 9 jam, sedangkan rata-rata pola tidur bayi posttest sebesar 12,4 jam, dengan standar deviasi 1,05 , pola tidur bayi tertinggi sebesar 15 jam dan terendah 10 jam.
Rata-rata pola tidur bayi pada kelompok eksperiment pretest di BPM Bidan E Kurnia Kabupaten Garut tahun 2020 sebesar 12,5 jam dengan standar deviasi 1,02 , pola tidur tertinggi sebesar 14 jam dan pola tidur terendah sebesar 11 jam, sedangkan rata-rata pola tidur bayi posttest sebesar 14,6 jam, dengan standar deviasi 1,47, pola tidur bayi tertinggi sebesar 16 jam dan terendah 11 jam.

Tabel 4.

Rata-rata Pola Tidur Bayi pada masing-masing kelompok

\begin{tabular}{lcccccc}
\hline \multicolumn{1}{c}{ Kelompok } & N & Mean & Min & Max & Sd & Se \\
\hline Kontrol & & & & & & \\
Pretest & 24 & 12,3 & 9 & 15 & 1,49 & 0,30 \\
Posttest & 24 & 12,4 & 10 & 15 & 1,05 & 0,21 \\
$\begin{array}{l}\text { Eksperimen } \\
\text { Pretest }\end{array}$ & 24 & 12,5 & 11 & 14 & 1,02 & 0,21 \\
Posttest & 24 & 14,6 & 11 & 16 & 1,47 & 0,30 \\
\hline
\end{tabular}

Tabel 5.

Pengaruh Pijat Bayi Terhadap Berat Badan Bayi

\begin{tabular}{lccccc}
\hline \multicolumn{1}{c}{ Kelompok } & N & Mean & Sd & Se & p value \\
\hline Kontrol & & & & & \\
Pretest & 24 & 6137,5 & 615,6 & 125,7 & 0,610 \\
Posttest & 24 & 6129,2 & 604,9 & 123,5 & \\
Eksperimen & & & & & \\
Pretest & 24 & 6729,2 & 764,1 & 155,9 & 0,000 \\
Posttest & 24 & 6912,5 & 778,7 & 158,9 & \\
\hline
\end{tabular}

Tabel 5 menunjukkan bahwa nilai rata-rata pretest pada kelompok kontrol sebesar $6137,5 \mathrm{gram}$ sedangkan rata-rata posttest sebesar 604,9 gram, karena nilai rata-rata pretest lebih besar daripada nilai posttest, maka dapat disimpulkan bahwa terjadi penurunan berat badan pada bayi pada kelompok kontrol di BPM Bidan E Kurnia Kabupaten Garut Tahun 2020.

Tabel 6.

Pengaruh Pijat Bayi Terhadap Pola Tidur Bayi

\begin{tabular}{lccccc}
\hline \multicolumn{1}{c}{ Kelompok } & N & Mean & Sd & Se & p value \\
\hline Kontrol & & & & & \\
Pretest & 24 & 12,3 & 1,49 & 0,30 & 0,833 \\
Posttest & 24 & 12,4 & 1,05 & 0,21 & \\
Eksperimen & & & & & \\
Pretest & 24 & 12,5 & 1,02 & 0,21 & 0,000 \\
Posttest & 24 & 14,6 & 1,47 & 0,30 & 0,47 \\
\hline
\end{tabular}

Tabel 6 menunjukkan bahwa nilai rata-rata pretest pada kelompok kontrol sebesar 12,3 jam sedangkan rata-rata posttest sebesar 12,4 jam, karena nilai rata-rata pretest lebih besar daripada nilai posttest, maka dapat disimpulkan bahwa terjadi penurunan pola tidur pada bayi pada kelompok kontrol di BPM Bidan E Kurnia Kabupaten Garut Tahun 2020.

\section{PEMBAHASAN}




\section{Sri Dinengsih, Refina Eka Yustiana}

Touch therapy ata massage (pemijatan) adalah salah satu tekhnik yang mengkombinasikan manfaat fisik sentuhan manusia dengan manfaat emosional seperti ikatan batin (bounding). Aktifitas pijat menimbulkan kontak antara anak dan orang tua, anak akan merasakan tentram dan nyaman karena dampak psikologis dari pemijatan ini adalah menyatakan rasa sayang. Pijat merupakan stimulasi taktil yang memberikan efek biokimia dan efek fisiologi pada berbagai organ tubuh. Pijat yang dilakukan secara benar dan teratur pada bayi diduga memiliki berbagai keuntungan dalam proses tumbuh kembang bayi. Pijat pada bayi oleh orangtua dapat meningkatkan hubungan emosional antara orangtua dan bayi, juga diduga dapat meningkatkan berat badan bayi hubungaemosional antara orangtua dan bayi, juga diduga dapat meningkatkan berat badan bayi meningkatkan berat badan bayi (Yuliana dkk, 2013)

Nilai rata-rata pretest pada kelompok eksperimen sebesar 6729,2 gram sedangkan ratarata posttest sebesar 6912,5 gram, karena nilai rata-rata pretest lebih kecil daripada nilai posttest, maka dapat disimpulkan bahwa terjadi peningkatan berat badan pada bayi pada kelompok eksperiment di BPM Bidan E Kurnia Kabupaten Garut Tahun 2020 sebesar 183,3 gram

Pemijatan pada bayi akan merangsang nervus vagus, dimana saraf ini akan meningkatkan peristaltik usus sehingga pengosongan lambung meningkat dengan demikian akan merangsang nafsu makan bayi untuk makan lebih lahap dalam jumlah yang cukup. Selain itu nervus vagus juga dapat memacu produksi enzim pencernaan sehingga penyerapan makanan maksimal. Disisi lain pijat juga dapat memperlancar peredaran darah dan meningkatkan metabolisme sel, dari rangkaian tersebut berat badan bayi akan meningkat (Hady 2014).

Pijat bayi sudah beberapa waktu ini digemari karena bisa membuat bayi lebih sehat dan tidak rewel. Pijat bayi juga bisa membuat otot bayi lebih kuat, imunitasnya meningkat, menaikkan berat badan bayi, mengurangi rasa sakit, dan membuat tidur bayi lebih lelap. Pijat bayi bisa merangsang otot motorik, memperbaiki kekebalannya serta menambah jumlah produksi darah putih yang membuat menjadi lebih sehat. Dengan memberikan pijatan pada tubuh si bayi nantinya membuat tubuh bayi mengalami penurunan hormon kortisol, yaitu hormon penyebab stres. Hasilnya bayi menjadi lebih riang dan tidak suka menangis. Jika bayi mengalami masalah berat badan, memijatnya

Peneliti berasumsi bahwa terjadinya kenaikan berat badan bayi pada kelompok yang secara teratur juga memberikan manfaat untuk mempengaruhi rangsangan syaraf dan kulit dan memproduksi hormon-hormon berpengaruh dalam menaikkan berat badan (Sekartini, R. 2012).

Pijat bayi sangat bermanfaat dalam mengoptimalkan pertumbuhan dan perkembangan anak, diantaranya adalah meningkatkan penyerapan makanan sehingga bayi lebih cepat lapar dan bayi akan lebih sering menyusu kepada ibunya, sehingga bisa meningkatkan berat badan pada bayi. Selain itu bayi yang rutin dilakukan pemijatan juga akan terjadi peningkatan kualitas tidurnya, yaitu bayi tidur lebih lelap dan meningkatkan kesiagaan, akibat dari adanya pengubahan gelombang otak. Bayi juga akan lebih kuat sistem kekebalan tubuhnya, sehingga akan meminimalkan terjadinya sakit. Penelitian terkait manfaat pijat bayi adalah bahwa pijat bayi bisa meningkatkan berat badan dan pertumbuhan, meningkatkan daya tahan tubuh dan membuat bayi tidur lelap (Setiawan, 2015)

Bayi yang dilakukan pemijatan rutin akan lebih cepat peningakatan berat badannya, hal ini sesuai dengan penelitian sebelumnya yang telah dilakukan oleh Dewi yang menyatakan bahwa pijat bayi dapat meningkatkan berat badan bayi lebih banyak dibanding tidak dipijat (Choirunisa, 2009). Informasi yang didapatkan dari lbu yang bayinya dilakukan intervensi pijat mengatakan bahwa anaknya sering lapar dan akhirnya frekuensi menyusui lebih sering daripada sebelum dilakukan pijat. Hal ini sesuai dengan teori yang menyatakan bahwa bayi yang sering dilakukan pemijatan akan meningkatkan tonus saraf vagus, yang meningkatkan pengeluaran hormon penyerapan makanan dan peningkatan kadar enzim gastrin dan insulin, sehingga penyerapan makanan akan lebih baik dan maksimal. Itulah yang menyebabkan mengapa bayi yang dilakukan pemijatan secara rutin akan lebih cepat terjadi peningkatan berat badannya dibanding yang tidak dipijat (Sulung dkk, 2015).

Peneliti berasumsi bahwa terjadinya kenaikan berat badan bayi pada kelompok yang diberikan pijat bayi disebabkan karena adanya rangsangan yang dilakukan melalui sentuhan. Pijat mempengaruhi sistem saraf dari tepi sampai pusat. Tekanan pada reseptor saraf dikulit akan menyebabkan pelebaran vena, arteri dan kapiler sehingga akan menghambat penyempitan, melemaskan keteganganotot, melambatkan detak jantung dan meningkatkan gerakan usus disaluran cerna.

diberikan pijat bayi disebabkan karena adanya rangsangan yang dilakukan melalui sentuhan. Pijat 


\section{JKM (Jurnal Kebidanan Malahayati),Vol 7,No.2.April 2021, \\ ISSN (Print) 2476-8944 ISSN (Online) 2579-762X, Hal 332-339}

mempengaruhi sistem saraf dari tepi sampai pusat. Tekanan pada reseptor saraf dikulit akan menyebabkan pelebaran vena, arteri dan kapiler sehingga akan menghambat penyempitan, melemaskan keteganganotot, melambatkan detak jantung dan meningkatkan gerakan usus disaluran cerna

Nilai rata-rata pretest pada kelompok eksperimen sebesar 12,5 jam sedangkan rata-rata posttest sebesar 14,6 jam, karena nilai rata-rata pretest lebih kecil daripada nilai posttest, maka dapat disimpulkan bahwa terjadi peningkatan pola tidur pada bayi pada kelompok eksperiment di BPM Bidan E Kurnia Kabupaten Garut Tahun 2020 sebesar 2,1 jam.

Tidur adalah salah satu bentuk adaptasi bayi terhadap lingkungannya. Sesaat setelah lahir, bayi biasanya tidur selama 16-20 jam sehari. Memasuki usia 2 bulan bayi mulai lebih banyak tidur malam dibanding siang. Sampai usia 3 bulan, bayi baru lahir akan menghabiskan waktu tidurnya sekitar 1517 jam, dengan pembagian waktu 8 jam untuk tidur siang dan 9 jam untuk tidur malam. Semakin usia bayi bertambah, jam tidurnya juga semakin berkurang. Pada usia 3-6 bulan jumlah tidur siang semakin berkurang, kirakira 3 kali. Total jumlah waktu tidur bayi usia 0-6 bulan berkisar antara 1315 jam/hari. Pada bayi usia 6 bulan pola tidurnya mulai tampak mirip dengan orang dewasa. Tidur nyenyak sangat penting bagi pertumbuhan bayi, karena saat tidur pertumbuhan otak bayi mencapai puncaknya. Selain itu pada saat tidur tubuh bayi memproduksi hormon pertumbuhan tiga kali lebih banyak dibandingkan ketika bayi terbangun (Galenia, 2014).

Touch Research Institute Amerika yang menunjukkan bahwa anak-anak yang dipijat selama 2x15 menit setiap minggunya dalam jangka waktu 4 minggu, juga memberikan hasil bahwa tidurnya menjadi lebih nyenyak sehingga pada waktu bangun konsentrasinya lebih baik daripada sebelum diberi pemijatan the relationship massage infant with pattern and sleep in infants menyimpulkan bahwa sentuhan-sentuhan yang diberikan pada saat pijat bayi memiliki hubungan dengan peningkatan kualitas tidur bayi yang ditunjukkan dengan peningkatan jumlah durasi tidur bayi serta berkurangnya gangguan tidur bayi (Nurmalasari, 2016).

Pijat bayi membantu merangsang kekebalan (pembawaan lahir) pada bayi, sehingga bisa membantu melawan infeksi. Sentuhan dan pijat pada bayi setelah kelahiran dapat memberikan jaminan adanya kontak tubuh yang berkelanjutan yang dapat mempertahankan perasaan aman pada bayi. Teknik pijat bayi khusus dapat membantu menghilangkan kulik (mulas), masuk angin, dan susah buang air besar. Selain itu pijat juga merangsang keluarnya hormon oksitosin, hormon oksitosin dihasilkan oleh hipotalamus. Hipotalamus memerintahkan pituitary untuk mensekresikan oksitosin, efek yang terjadi pada tubuh bayi menjadi tenang, nyaman dan mengurangi frekuensi menangis. Dengan demikian, pijatan juga meningkatkan kualitas tidurnya.( Roesli Utami, 2013)

bayi usia 3-6 bulan di wilayah kerja Puskesmas II Denpasar Timur mengalami peningkatan kualitas tidur setelah diberikan intervensi pijat bayi pada 21 responden (70\%). Di Depok, Sleman Yogyakarta, menunjukkan bahwa kualitas tidur setelah dilakukan pemijatan menunjukkan sebagian besar responden mempunyai kualitas tidur dalam kategori baik yaitu 20 responden $66,7 \%$ dan rata-rata mengalami peningkatan kualitas tidur pada setiap umur.( Latif, 2017)

Peningkatan kualitas tidur pada bayi yang diberi pemijatan tersebut disebabkan oleh adanya peningkatan kadar sekresi serotonin yang dihasilkan pada saat pemijatan, efek yang terjadi pada tubuh bayi menjadi tenang, nyaman dan mengurangi frekuensi menangis Rasa nyaman pada bayi setelah dipijat itu seperti apa yang dijelaskan dalam konsep Teori Kenyamanan (Theory of Comfort Katherine Kolcaba) yang menjelaskan konsep teori kenyamanan adalah kebutuhan kenyamanan, intervensi kenyamanan, intervening variabels, peningkatan kenyamanan health seeking behavior (HSBs) dan Integritas institusional. Pijat termasuk dalam intervensi kenyamanan (Comfort measures) yaitu intervensi yang sengaja dirancang untuk meningkatkan kenyamanan klien atau keluarga (Rosalina, 2015)

Peneliti berasumsi bahwa pijat bayi efektif dalam meningkatkan kualitas tidur bayi. Sesudah dilakukan pijat bayi sebagian besar kualitas tidur bayi menjadi baik. Kualitas tidur bayi baik menjadikan kebutuhan tidur bayi terpenuhi dengan baik sehingga proses pertumbuhan otak dan produksi hormon pertumbuhan yang terjadi pada saat bayi tidur akan terpenuhi dengan baik.

\section{SIMPULAN}

Ada pengaruh pijat bayi terhadap peningkatan berat badan dan ada pengaruh pijat bayi terhadap peningkatan pola tidur pada bayi. 


\section{Sri Dinengsih, Refina Eka Yustiana}

\section{SARAN}

Di perlukan upaya memberikan penyuluhan dan demonstrasi kepada ibu terutama ibu yang mempunyai bayi tentang pijat bayi Disarankan bagi ibu dan keluarga untuk melakukan pijat pada bayi sehingga dapat meningkatkan berat badan dan pola tidur, dan lebih mempelajari cara melakukan pijat bayi yang benar dengan cara berkonsultasi dengan

Abdurrahman, S. M. (2015). Pengaruh pijat bayi terhadap kualitas tidur bayi di Desa Tabumela Kecamatan Tilango Kabupaten Gorontalo. Skripsi, 1(841411037).

Adroeni, M., \& Hidayat, A. (2015). Pengaruh Pijat Bayi terhadap Kenaikan Berat Badan Bayi Umur 0-3 Bulan di BPS Saraswati Sleman Yogyakarta Tahun 2011 (Doctoral dissertation, STIKES'Aisyiyah Yogyakarta).

Choirunisa, 2009. Panduan Terpenting Merawat Bayi dan Balita di dalam Buku Ajar Dasar Keperawatan Anak. Jakarta: EGC.

Dasuki, M. S., \& Endy Parjanto, S. A. K. (2003). Pengaruh pijat bayi terhadap kenaikan berat badan bayi umur 4 bulan (Doctoral dissertation, [Yogyakarta]: Universitas Gadjah Mada).

Daniati, M., \& Novayelinda, R. (2011). Pengaruh pijat bayi terhadap peningkatan berat badan neonatus. Jurnal Ners Indonesia, 2(1), 1120.

Dewi, U., Aminin, F., \& Gunnara, H. (2014). Pengaruh Pemijatan terhadap Kualitas Tidur Bayi Usia 3-4 Bulan di Posyandu Gelatik dan Nuri Kelurahan Tanjungunggat Wilayah Kerja Puskesmas Sei Jang Kota Tanjungpinang Tahun 2014. Jurnal Ners dan Kebidanan (Journal of Ners and Midwifery), 1(3), 230-235.

Herliyanti, P. (2020). Pengaruh Pijat Bayi Terhadap Kualitas Tidur Pada Bayi Usia 0-6 Bulan (Doctoral Dissertation, Poltekkes Kemenkes Kendari).

Fauziah, 2018. Pengaruh Pijat Bayi Terhadap Kenaikan Berat Badan Dan Kualitas Tidur Bayi Di Puskesmas Jetis Yogyakarta. Placentum: Jurnal IImiah Kesehatan Dan Aplikasinya, $\quad 6(2), \quad$ 14-19. https://doi.org/0.13057/placentum.v\%vi\%i.22 834.

Galenia, 2014. Sentuhan Ajaib untuk Optimalkan Kecerdasan dan Tumbuh Kembang Buah Hati. Bandung.

Hady 2014. Pengaruh Pemijatan pada bayi terhadap peningkatan berat badan di wilayah kerja Puskesmas Weoe Kecamatan Wewiku bidan setempat. untuk penelitian selanjutnya diharapkan melakukan pengembangan penelitian pada faktor lain yang berpengaruh terhadap pijat bayi ataupun berat badan dan kualitas tidur pada bayi

\section{DAFTAR PUSTAKA}

Kabupaten Belu. Naskah Publikasi. Stikes Nani Husada Pare pare.

Ifalahma, D., \& Sulistiyanti, A. (2016). Efektivitas Pijat Bayi Terhadap Kualitas Tidur Bayi di Kelurahan Kadipiro Banjarsari Surakarta. Infokes: Jurnal IImiah Rekam Medis dan Informatika Kesehatan, 6(2).

Irva, 2014. Pengaruh Terapi Pijat Terhadap Peningkatan Berat Badan Bayi. Jom Psik. Volume 1. Nomor 2.

Kalsum, U. (2014). Peningkatan Berat Badan Bayi Melalui Pemijatan. Jurnal Keperawatan Indonesia, 17(1), 25-29.

Kemenkes RI, 2009. Pedoman Pelaksanaan Program Rumah Sakit Sayang Ibu dan Bayi (RSSIB). Jakarta: Kementerian Kesehatan Republik Indonesia.

Kemenkes RI, 2018. Kesehatan dalam Kerangka Sistainable Development Goals (SDG'S). Jakarta: Kementerian Kesehatan RI

Kemenkes, 2014. Riset Kesehatan Dasar. Jakarta: Badan Penelitian dan Pengembangan Kesehatan Kemenkes RI

Latif, 2017. Hubungan Pijat Bayi Terhadap Kenaikan Berat Badan Pada Bayi Berat Lahir Rendah (BBLR) Di RSKIA Ummi Khasanah Yogyakarta Tahun 2016. Skripsi. Politeknik Kesehatan Kemenkes Yogyakarta.

Maharani, S., Sukowati, F., \& Ulfiana, E. (2017). Pengaruh Kombinasi Pijat Bayi Dengan Musik Klasik Mozart Terhadap Berat Badan Dan Kualitas Tidur Bayi Usia 3-6 Bulan. Jurnal Kebidanan, 6(13), 57-63.

Nurmalasari, 2016. Pengaruh Pijat Bayi Dengan Kualitas Tidur Bayi Usia 3-6 Bulan Di Desa Bandung Kecamatan Diwek Kabupaten Jombang. Jurnal Penelitian. 148-1-1020180519.

Pamungkas, B. A., Susilaningsih, E. Z., Kp, S., \& Kep, M. (2016). Pengaruh Pijat Bayi Terhadap Kualitas Tidur Bayi Umur 0-6 Bulan di Puskesmas Kartasura (Doctoral dissertation, Universitas Muhammadiyah Surakarta).

Pratyahara, 2012. Keajaiban Terapi Sentuhan untuk Bayi Anda. Yogyakarta: Javalitera 
Roesli Utami, 2008. Pedoman Pijat Bayi. Trubus Agriwidya : Jakarta.

Roesli Utami, 2013. Pedoman Pijat Bayi (Edisi Revisi). Jakarta: PT Trubus Agriwidya.

Rosalina, 2015. Fisiologi Pijat Bayi. Bandung : Trikarsa

Setiawan, 2015. Pemberian Terapi Pijat Bayi Terhadap Kualitas Tidur Bayi Pada Asuhan Keperawatan An.N Dengan Infeksi Saluran Pernafasan Akut Di Ruang Melati RSUD Karanganyar. [Thesis]. Surakarta: STIKES Kusuma Husada

Shadik, N., \& Karjiyem, K. (2011). Pengaruh Pijat Bayi Terhadap Kualitas Tidur Bayi Usia 612 Bulan Di Rumah Bersalin Rachmi Yogyakarta Tahun 2011 (Doctoral dissertation, STIKES'Aisyiyah Yogyakarta).

Shofa, L., \& Yunani, H. R. (2014). Pengaruh pijat bayi terhadap kualitas tidur bayi usia 3-6 bulan di poliklinik kesehatan Desa Purworejo Kecamatan Bonang Kabupaten Demak. Jurnal Tidak Dipublikasikan.

Sulung dkk, 2015. Efektivitas Massage Baby Terhadap Peningkatan Berat Badan Bayi Usia 3-4 Bulan Di BPS BUNDA Kecamatan Mandiangin Koto Selayan Bukittinggi Tahun 2014. Menara llmu. Volume 9. Nomor 57

Tang, A., \& Aras, D. (2018). Pengaruh Pijat Bayi Terhadap Kualitas Tidur Bayi Usia 1-4 Bulan. GLOBAL HEALTH SCIENCE (GHS), 3(1), 12-16.

Yuliana dkk, 2013. Perbedaan berat badan bayi usia 3-5 bulan yang dipijat dan tidak dipijat (di Kelurahan Tawanganom Kecamatan Magetan tahun 2013). Jurnal Penelitian Kesehatan Suara Forikes. Volume 4. Nomor 4. 